\title{
NOTES ON RARE AND INTERESTING ROTIFERS (ROTIFERA: EUROTATORIA) FROM LOKTAK LAKE, MANIPUR - A RAMSAR SITE
}

\author{
B.K. Sharma
}

Department of Zoology, North-Eastern Hill University, Shillong, Meghalaya 793022, India

Email: bksharma@nehu.ac.in, profbksharma@ hotmail.com

\section{Abstract}

Eleven interesting species of Phylum Rotifera, belonging to seven families and seven genera, are documented from Loktak lake (a Ramsar site), Manipur, northeastern India. One species is a new record from the Oriental region, six species are new records from India, three species are new records from northeastern India and one species represents a new record illustrated, and remarks are made on their distribution.

\section{KEYWORDS}

India, Loktak, new records, oriental region, Ramsar site, rotifera

Loktak, a Ramsar site and one of the largest natural freshwater lakes of India, is experiencing severe environmental stress and serious habitat degradation. Attempts are being initiated for management of this important wetland as well as for biodiversity conservation of this hotspeck. So far very little is known about the micro-faunal diversity of Loktak lake in general and that of Phylum Rotifera in particular. The information on the latter is restricted to a preliminary list by Singh (1991).

The present communication, a part of study on biodiversity of Rotifera of Loktak lake, deals with 11 rare and interesting species including one new record from the Oriental region, six new records from India, three new records from northeastern region and one new record from Manipur. The examined species are briefly diagnosed and illustrated. In addition, comments are made on their distribution.

\section{Materials And Methods}

The present study is a part of limnological survey undertaken (during November 2002 - October 2004) in Loktak lake $\left(90^{\circ} 46^{\prime}-90^{\circ} 51^{\prime} \mathrm{E} \& 24^{\circ} 25^{\prime}-24^{\circ} 42^{\prime} \mathrm{N}\right.$; area: $286 \mathrm{~km}^{2}$; altitude: $768.5 \mathrm{~m}$ ) located in Bishnupur/Imphal districts of Manipur. The most common aquatic plants of this wetland include Hyrdrilla verticillata, Naias graminca, Euryale ferox, Vallisnaria spiralis, Utricularia flexuosa, Trapa natans, Eichhornia crassipes, Lemna trisula, Pistia striates, Salvenia sp., Nymphaea spp., Nymphoides spp., Nelumbo mucifera, Potamogeton spp., Azolla pinnata, Sagittaria spp, and Cyperus spp. etc.

Qualitative plankton samples were collected by towing a nylobolt plankton net (No. 25) from different parts (pats) of Loktak lake and were preserved in $5 \%$ formalin. Permanent mounts of individual species were made in polyvinyl alcohollectophenol mixture and glycerol. The rotifer taxa were identified following Donner (1965); Kutikova (1970); Koste (1978); Koste \& Shiel (1990); Shiel \& Koste (1992); Segers (1995); Nogrady \& Segers (2002). The illustrations of various species were drawn with Leitz-Dialux phase contrast from Manipur. The reported species are briefly diagnosed and

stereoscopic microscope using a drawing tube attachment. Measurements were indicated in micrometers $(\mu \mathrm{m})$.

Systematic list of the examined species
Phylum : Rotifera
Super Class : Eurotatoria
Class : Monogononta
Order : Ploimida
Family: Euchlanidae
Euchlanis semicarinata Segers, 1993 *

Family: Lepadellidae Lepadella bicornis Vasisht \& Battish, $1971^{* * *}$ Lepadella bengamini Harring, 1916 **

Family: Lecanidae

Lecane elegans Harring, 1914 **

Lecane tenuiseta Harring, 1914 **

Family: Gastropodidae

Ascomorpha ecaudis Perty, 1850 ***

Family: Trichocercidae

Trichocerca insignis (Herrick, 1885) **

Trichocerca tenuior (Hudson \& Gosse, 1886) **

Class : Bdelloidea

Order : Philodinida

Family : Philodinidae

Rotaria macroceros (Gosse, 1851) ***

Rotaria tardigrada (Ehrenberg, 1832)**

Family: Habrotrochidae

Habrotrocha angusticollis (Murray, 1905)

*- New record from the Oriental region; + - New record from Manipur; ${ }^{* *}$ - New record from India; ${ }^{* *}$ - New record from northeastern region

Taxonomic notes

1. Euchlanis semicarinata Segers, 1993

(Figs. 1-2)

Euchlanis semicarinata Segers, 1993, Hydrobiologia, 250, p. 4748 , figs. 8 , a-c.

Characters: Dorsal plate ovoid, truncate anteriorly, arched and its posterior end with a shallow median sinus; a characteristic median-dorsal keel present in posterior part of lorica. Ventral plate ovoid, flat, separated by lateral sulci. Lateral antennae located postero-laterally. Foot twosegmented; toes slender, parallel-sided and with pointed tips.

E. semicarinata can be differentiated from other keel bearing congeners namely $E$. incisa and E. triquetra by its incomplete median-dorsal keel.

Manuscript 1742; (C) ZOO; Date of publication 21 August 2007 Received 23 March 2007; Finally accepted 27 July 2007 


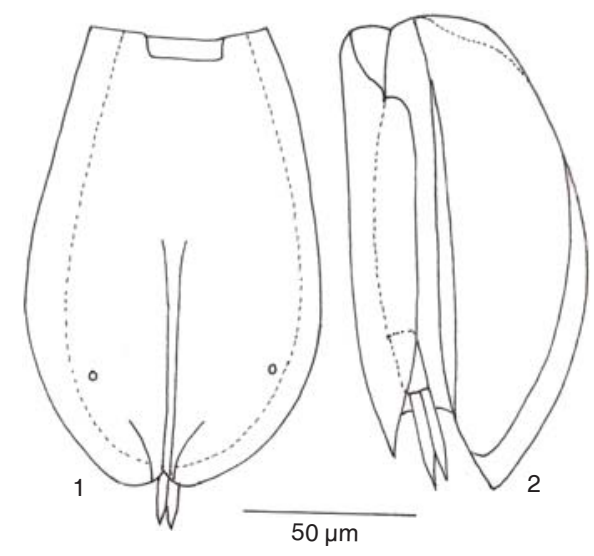

Figures 1-2. Euchlanis semicarinata Segers, 1993 1 - dorsal view; 2 - lateral view

Distribution: Represents a new record from the Oriental region. Elsewhere - reported so far from Africa and Papua New Guinea.

\section{Lepadella bicornis Vasisht \& Battish, 1971}

(Figs. 3-4)

Lepadella bicornis Vasisht \& Battish, 1971, Res. Bull. Panjab Univ., 22, p. 191, figs. 5-6; Segers et al., 1993, Belg. J. Zool., 123,. p.119120, Figs. 6 a-c

Lepadella ehrenbergi (Perty, 1850): Koste, 1974, Amazoniana, V (1), p. 35, Abb. 18.

Characters: Lorica broadly ovate, moderately compressed dorso-ventrally; with prominent acutely pointed broad-based corners laterally. Anterior dorsal margin concave and anterior ventral sinus v-shaped. Foot-groove shallow. Foot 4-segmented, distal foot-segment longest; toes equal and pointed.

Distribution: Northeastern India - new record. India: Chandigarh (U.T.). Elsewhere: Brazil (South America).
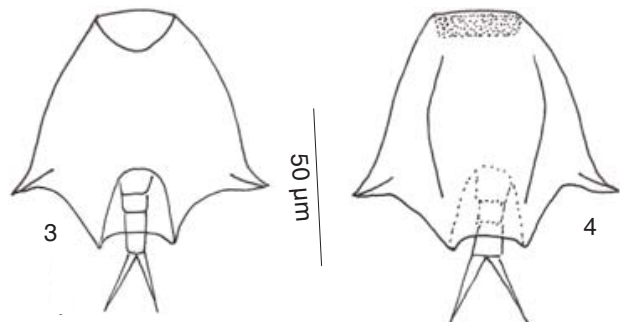

Figures 3-4. Lepadella bicornis Vasisht \& Battish, 1971 3 - ventral view; 4 - dorsal view

\section{Lepadella bengamini Harring, 1916}

(Figs. 5-8)

Lepadella bengamini Harring, 1916, Proc. U.S. Nat. Museum, 51 , p.548-549, Fig. 93: 1-8.

Characters: Lorica broadly oval, bulged in cross-section and with maximum width in its middle region. Head aperture nearly tubular, and its rim ventrally directed; anterior dorsal margin nearly straight and ventral margin with U-shaped

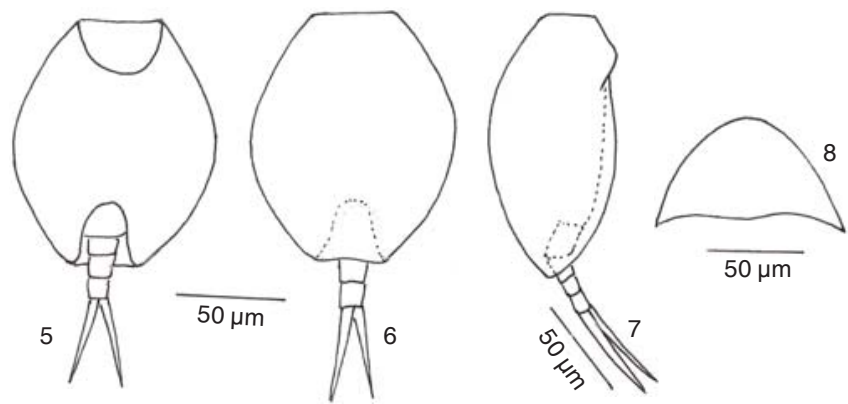

Figure 5-8. Lepadella bengamini Harring, 1916 5 - ventral view; 6 - dorsal view; 7 - lateral view; 8 - cross-section

sinus. Posterior end of lorica slightly concave. Foot-groove wider than its length and with divergent sides. Distal footsegment elongated and projecting beyond lorica. Toes long, pointed and gently ventrally curved.

Distribution: India - new record. Elsewhere: Cosmopolitan.

\section{Lecane elegans Harring, 1914 \\ (Fig. 9)}

Lecane elegans Harring, 1914, Proc. U.S. Nat. Museum, 47, p. 544545 , pl. 23, figs. 3,4 .

Characters: Lorica smooth, elongated and slender; anterior occipital margins nearly straight and coincident. Lateral sulci indistinct. Ventral plate with few longitudinal folds. Foot plate large. Second foot-segment elongated and project beyond lorica. Toes long, parallel-sided and slightly curved distally. Pseudo-claws long, curved and with distinct denticles and pointed tips.

Distribution: India - new record. Elsewhere: Pantropical.

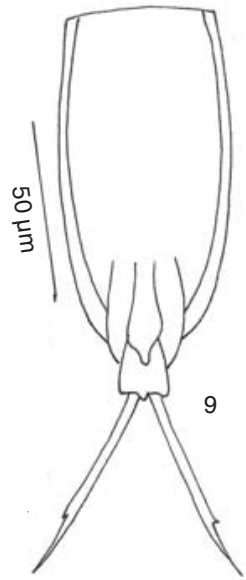

Figure 9. Lecane elegans Harring, 1914 ventral view

\section{Lecane tenuiseta Harring, 1914}

(Figs. 10-11)

Lecane tenuiseta Harring, 1914, Proc. U.S. Nat. Museum, 47, p. 543-544, plate 20, figs. 1-3; Koste,1978, ROTATORIA. Die Rädertiere Mitteleuropas, begründet von Max Voigt. Überordnung. 

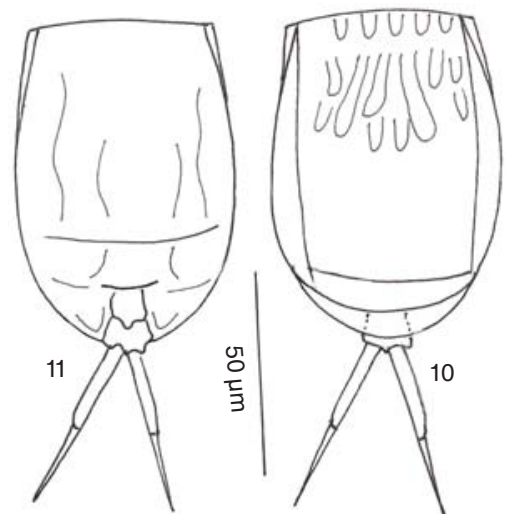

Figures 10-11. Lecane tenuiseta Harring, 1914 10 - dorsal view; 11 - ventral view

Monogononta. p.218, pl.72, figs. 7 a-b.

Lecane tenuiseta punctata: Kutikova, 1970, The rotifer fauna of the USSR. Fauna SSSR 104, p. 450, figs. 610-611.

Characters: Lorica oblong; anterior occipital margins coincident, slightly convex and antero-lateral corners angulated. Dorsal plate with some pattern and punctuate, narrow anteriorly and medially as wide as ventral plate. Ventral plate with few folds. Lateral sulci deep. Posterior segment rounded. Coxal plates large. Second foot-segment projecting a little beyond lorica. Toes long, slender, parallel-sided; terminating into separated long claws.

This lecanid is characterized by its long and completely separated claws. The present specimens are identical with $L$. tenuiseta punctata (vide Kutikova,1970) which, in turn, is now treated as a synonym (Koste, 1978; Segers, 1995) of L. tenuiseta.

Distribution: India - new record. Elsewhere: Cosmopolitan

\section{Ascomorpha ecaudis Perty, 1850}

(Figs. 12 - 13)

Ascomorpha ecaudis Perty, 1850, Mitt.naturforsch. Ges. Bern. 169/ 170, p. 18

Characters: Body sacciform and with maximum width at the distal third. Apical field with four long styli. Stomach with green-yellow or brown lobes; with four rounded defecation

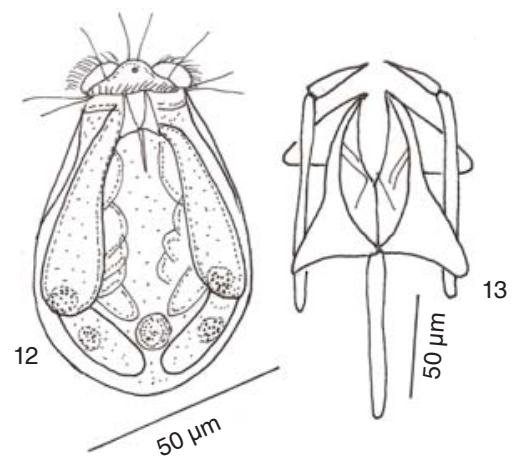

Figures 12-13. Ascomorpha ecaudis Perty, 1850 12 - dorsal view; 13 - trophi

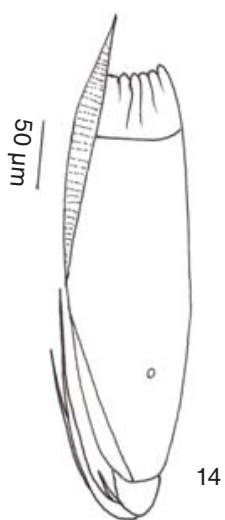

Figure 14. Trichocerca insignis (Herrick, 1885) lateral view

reservoirs. Vitellarium with eight nuclei. Trophi: rami with triangular alulae, uncus with single sharp tooth and manubria with small eyelet. Eggs attached to body.

Distribution: Northeastern India - new record. India: Kashmir. Elsewhere: Cosmopolitan.

\section{Trichocerca insignis (Herrick, 1885)}

(Fig. 14)

Diurella insignis Herrick, 1885, Bull. Sci. Lab. Dennison Univ., 1, p. 50 , Fig. 4.

Characters: Body elongated, cylindrical and tapering to foot in the posterior one-third part; lorica height: length ratio nearly 1:5. Lorica with two anterior projections/teeth of similar length. Keel starts between anterior projections/teeth and runs to posterior end of lorica. Foot short, demarcated from trunk. Toes unequal and ventrally curved; left toe nearly half the length of lorica, right toe nearly $2 / 3$ the left tow, substyli present. Trophi asymmetrical: fulcrum distally dilated, manubria rod-like, left manubrium curved inwards distally, rami and unci with denticles.

Distribution: India - new record. Elsewhere: Cosmopolitan.

\section{Trichocerca tenuior (Hudson \& Gosse, 1886)}

(Figs. 15-16)

Coelopus tenuior Hudson \& Gosse, 1886, The Rotifera or wheel

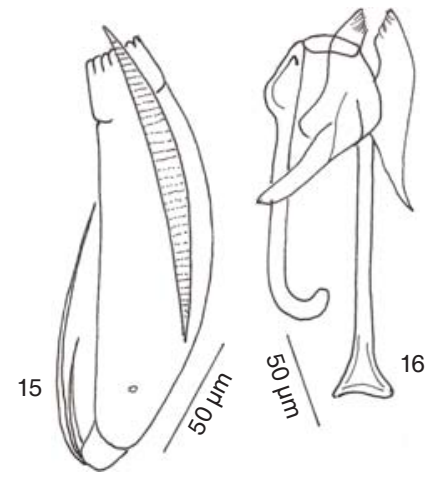

Figure 15-16. Trichocerca tenuior (Hudson \& Gosse, 1886) 15 - lateral view; 16 - trophi 
animalcules, both British and foreign, p. 68, Fig. 20: 19.

Characters: Body curved and elongated; with an acute tooth at right anterior margin of lorica; a low striated keel extending from base of tooth to nearly midline. Head marked off by suture and with longitudinal folds. Foot short, demarcated from trunk. Toes unequal; left tow curved ventrally and nearly half the length of lorica; right tow delicate half the length of left toe; substyli present. Trophi asymmetrical: fulcrum distally dilated, left manubrium curved inwards distally, right manubrium fragile straight rod, right ramus with triangular alula pointed almost at right angles to fulcrum

Distribution: India - new record. Elsewhere: Cosmopolitan.

\section{Rotaria macroceros (Gosse, 1851 )}

(Fig. 17)

Rotifer macroceros Gosse, 1851, Ann. Mag: Nat. Hist., ser 2, 8, p. 197.

Characters: Characterized by its very long antenna. Foot short when fully extended. Other details as per Donner (1965).

Distribution: Northeastern India - new record. India: West Bengal. Elsewhere: Cosmopolitan.

\section{Rotaria tardigrada (Ehrenberg, 1832)}

\section{(Fig. 18)}

Rotifer tardigradus Ehrenberg, 1832, Abh. Acad. Wiss. Berlin, p. 105. Rotaria tardigrada (Ehrenberg): Donner, 1965, Bestimmunsbücher Zur Bodenfauna Europas, 6, p. 170, Fig. 125 a-d

Characters: Ventral toes longer than spurs; spurs $>2$ times as long as width of foot segment they derive from. Often with detritus attached to trunk region. Antenna short. Other details as per Donner (1965)

Distribution: India-new record. Elsewhere: Cosmopolitan.

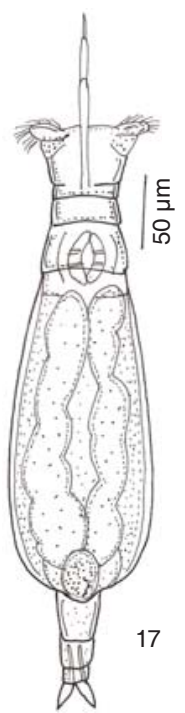

Figure 17. Rotaria macroceros (Gosse, 1851) 17 - dorsal view

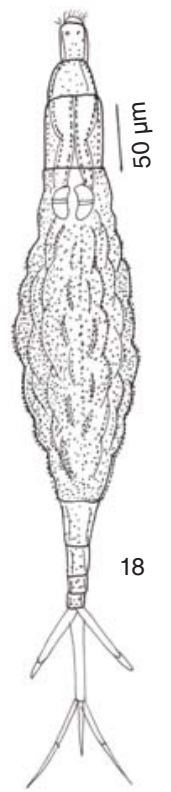

Figure 18. Rotaria tardigrada (Ehrenberg, 1832) dorsal view

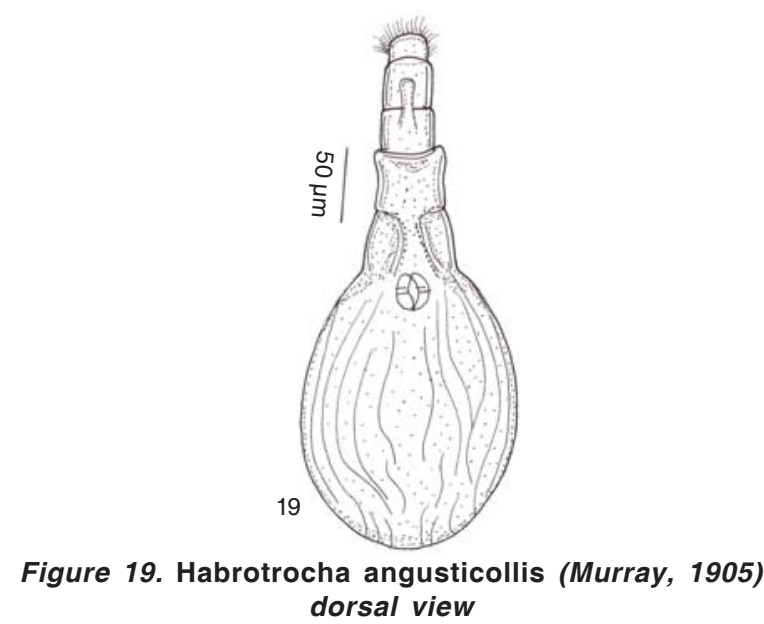

11. Habrotrocha angusticollis (Murray, 1905)

(Fig. 19)

Callindina angusticollis Murray, 1905, Trans. Roy. Soc. Edinburgh, 41, p. 370.

Characters: Foot extremely reduced. Characterized by gelatinous case. Other details as per Donner (1965).

Distribution: India - new record from Manipur; recorded earlier only from Sikkim Himalayas. Elsewhere: Cosmopolitan.

\section{REMARKS}

Eleven species of Rotifera, belonging to seven families and seven genera, are reported from Loktak lake (a Ramsar site), Manipur, N.E. India and, these include two Palaeotropical, one Pantropical and eight cosmopolitan species. Among these, Euchlanis semicarinata is a new record from the Oriental region. Six species namely Lepadella bengamini, Lecane elegans, L. 
tenuiseta, Trichocerca insignis, T. tenuior and Rotaria tardigrada are new records from India. In addition, three species i.e., Lepadella bicornis, Ascomorpha ecaudis and Rotaria macroceros are new records from northeastern India while Habrotrocha angusticollis is a new record from Manipur. The present report raises the Rotifera richness documented so far from northeastern India (Sharma \& Sharma, 2005) to 202 species belonging to 43 genera and 21 families. Further, all the recorded species represent rare elements in the examined collections as well as in the Indian Rotifera.

The occurrence of erstwhile Afro-tropical Euchlanis semicarinata in northeastern India merits special biogeographical interest. Described originally from Africa (Segers, 1993), this euchlanid has been examined from Papua New Guinea (Segers \& De Meester, 1994). The present report affirms its distribution in the tropical and subtropical regions of the old World. The case of distribution of the stated species holds parallel to another member of the Euchlanidae i.e., Dipleuchlanis ornata which was described by Segers (1993) from Africa and has recently been reported (Sharma, 2005) from the floodplains of the Brahmaputra river basin of lower Assam.

Of the new additions to the Indian Rotifera, Lepadella bengamini, a cosmopolitan species, also comprises a new report from the Indian subcontinent. It is so far reported from China and Thailand among the Asian countries. Lecane elegans, a pantropical element, is reported to have flexible lorica (Segers, $1995)$ but the present specimens agree with those reported from the Amazon basin (Koste, 1974). The examined specimens of Lecane tenuiseta are identical with L. tenuiseta punctata (vide Kutikova, 1970) and have characteristic pattern on dorsal plate of lorica. These are, however, treated as a synonym of the former following the works of Koste (1978) and Segers (1995). Trichocerca insignis, T. tenuior and Rotaria tardigrada are other rare and interesting additions to the rotifer fauna of India; the first species exhibits pancontinental distribution, with reports from Europe, North \& South America, New Zealand and Australia.

Among the new records from Northeastern region, Lepadella bicornis was originally described by Vasisht \& Battish (1971) from a fish pond at Chandigarh (northern India) and was not known from the Indian subcontinent since its description. Segers et al. (1993) provided the only confirmed report of this species from the Rio Abobral and Rio Paraguai (Pantal region, Brazil). On the other hand, it was erroneously identified as $L$. ehrenbergi from Rio Tapajos (Koste, 1974) and as L. pterygoida from Rio Nhamunda (Brandorff et al., 1982) from the Amazon region, Brazil. The specimens examined presently from Loktak lake, therefore, represent the second Indian report of this interesting palaeotropical species. Further, this report extends its distribution range to northeastern India.

Ascomorpha ecaudis and Rotaria macroceros are other two little known rotifers in the Indian waters that comprise new records from northeastern region. Of these, the former species has so far been reported from India only from Kashmir (Edmondson \& Hutchinson, 1934) and the present record extends its distributional limit to eastern Himalaya. On the other hand, the latter was known till date examined from Calcutta and its environs (Anderson, 1889). Habrotrocha angusticollis is yet another little known member of the Indian fauna; it has been reported earlier from Sikkim Himalaya (Murray, 1906) and has, hence, been now documented from this country after a lapse of one century. The reports of the stated three species of Bdelloidea deserve special mention in view of the limited information on their distribution in India in general and northeastern region in particular (Sharma \& Sharma, 2005).

\section{REFERENCES}

Anderson, H.H. (1889). Notes on Indian Rotifera. Journal of the Asiatic Society of Bengal 58: 345-358.

Brandorff, G.O., W. Koste \& N.N. Smirnov (1982). The composition and structure of Rotiferan and Crustacean communities of the lower Rio Nhamunda, Amazonas, Brazil. Studies on Neotropical Fauna Environs 17: 69-121.

Donner, J. (1965). Ordnung Bdelloidea (Rotatoria, Rädertiere). Bestimmungsbiucher Zur Bodenfauna Europas, Lieferung 6, Akademie-Verlag, Berlin, 297pp.

Edmondson, W.T. \& G.E. Hutchinson (1934). Report on Rotatoria. Article IX. Yale north Indian expedition. Memoirs of the Connecticut Academy of Arts and Sciences 10: 153-186.

Koste, W. (1974). Zur Kenntnis der Rotatorienfauna der "schwimmenden Wiese" eiener Uferlagune in der Várzea Amazoniens, Brasilien. Amazoniana V(1): 25-59. Koste, W. (1978). ROTATORIA. Die Rädertiere Mitteleuropas, begriindet von Max Voigt. Überordnung Monogononta. Gebrüder Borntaeger, Berlin, Stuttgart. I. Text (673 pp) U. II. Tafelbd. (T. 234).

Koste, W. \& R.J. Shiel (1990). Rotifera from Australian inland waters V. Lecanidae (Rotifera: Monogononta). Transactions of the Royal Society of South Australia 114(1): 1-36.

Kutikova, L.A. (1970). The rotifer fauna of the USSR. Fauna SSSR 104, Academia Nauk, 744pp (in Russian)

Murray, J. (1906). Some Rotifera of Sikkim Himalaya. Journal of the Royal Microscopical Society of London 9: 637-644.

Nogrady, T. \& H. Segers (2002). Rotifera: Asplanchnidae, Gastropodidae, Macrocodidae, Synchaetidae, Trochosphaeridae and Filinia. In: Guides to identification of the Microinvertebrates of the Continental waters of the world 6: 1-264. Backhuys Publishers. Leiden, The Netherlands.

Sharma, B.K. (2005). Rotifer communities of floodplain lakes of the Brahmaputra basin of lower Assam (N.E. India): biodiversity, distribution and ecology. Hydrobiologia 533: 209-221.

Sharma, B.K. \& S. Sharma (2005). Biodiversity of freshwater rotifers (Rotifera, Eurotatoria) from North-Eastern India. Mitteilungen aus dem Museum fir Naturkunde, Zoologische Reihe 81: 81-88.

Segers, H. (1993). Rotifera of some lakes in the floodplain of the river Niger (Imo State, Nigeria). I. New species and other taxonomic considerations. Hydrobiologia 250: 39-61.

Segers, H. (1995). Rotifera: Lecanidae. In: Guides to Identification of the Microinvertebrates of the Continental Waters of The World. 2. SPB Academic Publishing bv. Amsterdam, The Netherlands, 264pp.

Segers, H. \& L. De Meester (1994). Rotifera from Papua New Guinea, with the description of new Scaridium Ehrenberg, 1830. Archiv fir Hydrobiology 131(1): 111-125

Segers, H., E.N. dos Santos-Silva \& A.L. de Oliveira-Neto (1993). New and rare species of Lecane and Lepadella (Rotifera: Lecanidae: Colurellidae) from Brazil. Belgian Journal of Zoology 123: 113-121.

Shiel, R.J. \& W. Koste (1992). Rotifera from Australian inland waters VIII. Trichocercidae (Monogononta). Transactions of the Royal Society of South Australia 116(1): 1-27.

Singh, R.K.S. (1991). Study of mutrient enrichment in Loktak lake with reference to Biological indices. Ph.D Thesis, Manipur University, Manipur.

Vasisht, H.S. \& S.K. Battish (1971). The rotifer fauna of North India. Lepadella and Colurella. Research Bulletin (N.S.) of the Punjab University 22(1-11): 189-192.

\section{Acknowledgements}

This study was undertaken under the UGC "University with Potential for Excellence Scheme (UPE)" implemented in North-Eastern Hill University, Shillong (Focused Area-I: Biosciences). 